\title{
Five recent developments' impact on the traditional academic culture of Departments of Accounting at South African universities
}

\author{
DB van der Schyf \\ Department of Accounting \\ University of Pretoria
}

\begin{abstract}
The fact that Departments of Accounting at South African universities, whose academic programmes are accredited by the South African Institute of Chartered Accountants (SAICA), have for many years focused primarily only on the academic training of prospective chartered accountants, has established a culture that is removed from research, and this is in contrast to the nature of a university. The aim of this paper is to evaluate some recent developments in the South African academic environment that may promote a research culture and to point out the coercive role these developments may play in changing the existing culture of a Department of Accounting. The study concludes that in view of a list of specific recent developments in the national academic environment, Departments of Accounting will be forced to change course toward becoming more research oriented. A number of recommendations are made to expedite the process.
\end{abstract}

\section{Key words}

Departments of Accounting (South Africa)

Higher Education Qualifications Framework

IFAC's International Education Standards for Professional Accountants

International context of Departments of Accounting

Quality assurance in Departments of Accounting

SAICA's syllabus content

Scholarly activity (search for truthful knowledge in accounting)

The essence of a university

\section{Introduction}

The primary aim of this study is to briefly discuss a number of recent developments in the South African academic environment and to indicate their possible impact on the academic world in general and on Departments of Accounting in particular, in the near future. In this study, the term "Departments of Accounting" refers to the 14 universities (SAICA s.a.(b)) whose undergraduate and graduate programmes are accredited with the South African 
Institute of Chartered Accountants (SAICA) and whose syllabi are, by implication, also accredited by SAICA (s.a.(a)). The syllabus content that SAICA (2005:30/05) prescribes for students wishing to sit for Part 1 of the Qualifying Examination is currently not designed to promote research expertise.

Observation and academic experience reveal that the status currently enjoyed by Departments of Accounting in the academic and business community depends largely on whether their academic programmes are accredited by SAICA.

The implication of the recent developments is that, if Departments of Accounting wish to remain nationally and internationally relevant and competitive, they will perforce have to rethink their academic mission within a university. The primary academic activity of a South African Department of Accounting traditionally focuses on the academic training of prospective chartered accountants. It seems that, in view of the recent changes discussed in this article, a change in the academic culture in Departments of Accounting is inevitable.

The first of these developments is the aspiration of almost every South African university to pursue its scientific mission, to practise scholarly activity (search for truthful knowledge) competitively at national level and to enjoy international recognition - every Department of Accounting must be equally committed to this aspiration because all these departments are indissolubly part of the university and its policies.

A second development that will fundamentally affect such a department is the need to comply with the quality assurance obligation that has already been inscribed in Section 7 of the Higher Education Act 101 of 1997 for some time, but that must now be implemented. It requires, inter alia, that the academic activities of a department be assessed and measured in terms of international standards by an external panel and that any deficiencies should be reported to the university authorities (South Africa 1997a).

A third development that is closely related to the second is the new funding formula that was announced in Section 5 of the Department of National Education's National Plan for Higher Education (2001:71). This formula provides for research at universities to be funded by means of a separate formula based on research outputs. The Minister of Education announced A New Funding Framework in February 2004 (Department of Education 2004). This announcement was followed just over two years later by the Ministerial Statement on Higher Education Funding: 2006/2007 to 2008/2009 in May 2006 (Department of Education 2006). Since Departments of Accounting are part of the university set-up, they are directly affected by these particular developments, especially because these changes are part and parcel of the central government's objective of "research capacity building".

The fourth development also requires serious consideration by Departments of Accounting, namely the need to meet the requirement of the International Federation of Accountants' (IFAC 2003) International Education Standards for Professional Accountants - this involves, first, in short, that students who have completed their studies should have research skills and, second, that these students should have been exposed to accounting theory that would promote the student's "logical and analytical thinking, [and] powers of reasoning" (IFAC 2003:57). At present, these areas are not compulsory teaching disciplines in the academic training of potential chartered accountants.

The fifth and last development that Departments of Accounting need to take seriously and respond to is The Higher Education Qualifications Framework, a policy document issued by the Department of Education (2007) under the Higher Education Act 101 of 1997. According to this policy document, programmes for a bachelor honours degree "should 
include conducting and reporting research under supervision". Compulsory student exposure to "a high level of theoretical engagement and intellectual independence" is also required (Department of Education 2007:25). This is in line with IFAC's requirement that students who have completed their courses should have research and conceptual skills.

The university authorities are also applying increasing pressure on Departments of Accounting to engage actively in research and to form part of the research community participating in the search for truthful knowledge that is an essential part of the nature of a university. This is a vital step away from the traditional academic culture of Departments of Accounting.

Two accounting research journals have been established in the last 20 years, namely the South African Journal of Accounting Research (SAJAR) - previously called De Ratione (http://www.sajar.co.za), in 1987, and Meditari (http://www.meditari.org.za), in 1993. However, the research outputs published in these journals are not yet of an international standard. At the turn of the century, Gray and McKernan (2000:10) commented as follows: “... we see a difficulty facing South African accounting academics ... the research culture as understood in the Anglo-Saxon universities - has yet to develop and embed itself". Six years later, West (2006:121) reported that "the research outputs of accountancy academics in South Africa seem to lag far behind those of their counterparts abroad".

This study is primarily argumentative, and attempts to evaluate the possible impact of the five recent developments mentioned above on the traditional academic culture of a Department of Accounting.

As far as could be ascertained, no research in this particular field as has yet been published in South Africa.

\section{Literature review}

The primary literature consulted in this study is directly related to the above recent developments in the academic environment. The relevant literature was comprehensively consulted, but was concisely summarised in the article. For this reason, and because of the fact that, as far as could be determined, no similar research had thus far been undertaken in this field, it was difficult to position this study in the context of existing research literature.

\section{Problem statement, research design and methodology}

The problem statement that this article addresses can be expressed in the following question: What is the impact of five recent developments in the South African academic environment on the traditional academic culture of Departments of Accounting at South African universities?

The research design is a plan according to which a study is to be conducted (Mouton 2001:55). The research design is always based on the research question (Cooper \& Schindler 2003:146). The research question in this article was formulated as set out above. The research design should also answer the question of what research techniques are used in the study. In this study, a literature review was conducted and observations were made. The data that were gathered were primary data at an empirical level - the specific recent developments identified from the literature review that is verifiable by experience or observation. This research technique can hopefully make a contribution by ensuring that 
valid deductions are made and conclusions drawn on the basis of the research findings. The limitations of personal observations in this research are acknowledged.

A qualitative research methodology was followed in this study. Recent developments in the academic environment in which South African universities operate were critically assessed. This is in line with Henning's (2004:5) definition of "qualitative research" as "the type of enquiry in which the qualities, the characteristics or the properties of a phenomenon are examined for better understanding and explanation".

\section{Recent developments in the academic environment in which South African universities operate}

The research question that must be answered in this section of the article is the following: What is the impact of selected recent developments in the South African academic environment on the traditional academic culture of Departments of Accounting at South African universities? This research question is answered below, using an empirical approach and a qualitative methodology, as indicated above.

With regard to the role of the university, Koornhof (2004:7) cites the opinion of Karl Jaspers, a well-known German academic: "[T]eaching that is divorced from research would rob institutions of their basic impetus ... the combination of teaching and research formed the gist of university education". Rossouw (2006:2) defines the essence of a university as follows: "The university should be an institution ... that pursues scientific knowledge through learning, teaching and research ...". In short, this implies that the primary task of a university is scholarly activity (the search for truthful knowledge). Duderstadt (2000:124) and Larkin Kerwin, cited in The International Education Quotations Encyclopaedia (Noble 1995:240), also share this view.

This implies that all Departments of Accounting at South African universities should be active role players in the scholarly activity in accounting. The term "scholarly activity" is an alternative term for "scholarship". Cryer's (2006:73) view on the meaning of the term "scholarship" is as follows: "... [scholarship] - is the body of principles and practices used by scholars to make their claims about the world as valid and trustworthy as possible, and to make them known to the scholarly public. In its broadest sense, scholarship can be taken to include the scientific method, which is the body of scholarly practice that governs the sciences."

The scholarly activity responsibility of Departments of Accounting at South African universities, an essential part of the nature of a university, is becoming increasingly prominent in our time. There have been a number of recent developments relating to scholarly activity in accounting that require the urgent attention of such departments. These developments are discussed individually in this section, in line with the research question formulated above.

The following developments are examined: the international context of Departments of Accounting, such departments' quality assurance obligations, the effect(s) of the new funding formula for South African universities, of IFAC's International Education Standards for Professional Accountants, and of the Higher Educations Qualifications Framework. 


\subsection{The international context of Departments of Accounting}

Prominent international universities such as Oxford University (s.a.), the University of Cambridge (s.a.) and the Harvard Business School (s.a.) emphasise that they are internationally recognised. They all stress their competitiveness in their respective mission statements. All the academic departments at these institutions are clearly committed to the missions of their institutions to enable these institutions to fulfil their prominent international role.

It has become a common practice among South African universities to mention international recognition in their mission statements. Among these universities (the ones whose academic programmes are also accredited by SAICA) are the University of Cape Town (s.a.), the University of Pretoria (s.a.), Stellenbosch University (s.a.) and the University of the Witwatersrand (s.a.). Obviously the Departments of Accounting at these universities are bound to the mission statements of their respective institutions and, by implication, to the aspiration to achieve international recognition and to become internationally competitive. These departments must therefore take it for granted that they need to make a serious attempt to live up to their mandate to scholarly activity, because such an attempt by the university in general and by each Department of Accounting in particular is essential in order to gain international recognition and to be internationally competitive. If such departments fail to take this obligation as seriously as they should, they may expect to face the risk that they will receive a negative report when, in the process of quality assurance, an external panel using international standards as its benchmark must report on the department's lack of compliance in this regard.

Finally, in respect of the international role of South African universities, one should note Professor Max Price's view in this regard, as expressed in his speech accepting the vicechancellorship of the University of Cape Town: "Universities can be thought of as nodes in global networks of knowledge-creating institutions. A university that does not actively insert itself into these global networks in the areas of research, teaching and exchanges will rapidly slip into the second league ... The graduate of tomorrow will, and must, be internationally mobile ... This requires, among other things, ensuring our students get an international education and global networks of colleagues" (Sunday Times 13 October 2007 s.a.).

South African Departments of Accounting should also take cognisance of this trend and think seriously about their international role.

\subsection{The quality assurance obligations of Departments of Accounting}

It is imperative that Departments of Accounting thoroughly understand their quality assurance obligations in the university context and in the higher education sphere. The Higher Education Act 101 of 1997 makes provision for the establishment of a Council on Higher Education (CHE) (South Africa 1997a: Section 4). Section 5 of the Act spells out the various functions of the CHE. For the purposes of this discussion, it should be mentioned that one of the principal functions of the CHE is to "promote quality assurance in higher education" (South Africa 1997a: Section 5(1)(c)(i)). According to the CHE's Founding Document ( $2^{\text {nd }}$ edition) of December 2004 (CHE 2004a:4), Section 14 of the South African Qualifications Authority (SAQA) Act 58 of 1995 (South Africa 1995) makes 
provision for regulations governing the accreditation of Education and Training Quality Assurance bodies (ETQAs) ... the CHE will have to meet the criteria and guidelines laid down by SAQA to be an ETQA in Higher Education Training (HET). SAICA is also listed in the CHE's Directory of South African Education and Training Quality Assurers and Professional Bodies in Section $\mathrm{C}$ of the Directory under "Professional Bodies and Institutes (Non-Statutory)" with ETQA status (CHE 2003).

The White Paper on Higher Education (South Africa 1997b: Section 3.28) and the Higher Education Act of 1997 (South Africa 1997a: Section 7.1) make provision for the CHE to establish a permanent subcommittee, the Higher Education Quality Committee (HEQC). The HEQC's (s.a.) mandate is to

$\square$ promote quality assurance in higher education

$\square$ audit the quality assurance mechanisms of higher education institutions

$\square$ accredit programmes of higher education

The HEQC (fulfilling the role of the CHE's ETQA status) will seek delegated authority from SAQA; and the CHE will make the arrangements it deems appropriate to operate within the policy framework and procedural guidelines established by SAQA (South Africa 1997b: Section 3.28).

The HEQC was formally launched in 2000 (Strydom \& Strydom 2004). For more information on the HEQC's Founding Document on quality assurance and the establishment of quality assurance in the South African context, the reader is referred to Strydom and Strydom's (2004) article. For complete details on the functioning and publications of the HEQC, the reader is referred to the organisation's website, namely http://www.che.ac.za/heqc/heqc.php.

The HEQC's mandate affects every Department of Accounting at every South African university, since all universities (this implies its faculties, schools and academic departments) are subject to a quality assurance audit. A quality assurance audit will determine, inter alia, whether a Department of Accounting displays a serious commitment to research and to what extent it meets that commitment. Without oversimplifying the aim of the legislation, one can reasonably say that the Higher Education Act uses the quality assurance requirement to create a climate conducive to shifting even typical (nonresearching) Departments of Accounting to bring their academic activities into line with the "essence of a university".

Note that paragraph 2.7.2.2 of the HEQC's (CHE 2004b) policy document Framework for Institutional Audits requires every university to subject itself to a self-evaluation exercise at least 10 weeks before the scheduled quality assurance audit and to develop an audit portfolio that is submitted to the HEQC. The audit portfolio indicates how the institution manages the quality of its core academic activities. The audit portfolio serves as the basis of the final quality assurance audit. The self-evaluation exercise also provides Departments of Accounting with an ideal opportunity to prepare themselves for the final quality assurance audit.

For the purposes of quality assurance on its research activities, it is worth a Department of Accounting's while to master the content of A Good Practice Guide for Quality Management of Research for Higher Education Institutions issued by the CHE in July 2005. The following statement in that document emphasises the value of making this effort: “... it [research management] provides the policies, structures, processes and mechanisms 
to assure, develop, support and monitor the actual quality of research and postgraduate education, which in turn is measured and judged by peers through a host of local and international review and evaluation mechanisms" (CHE 2005:4).

\subsection{The implications of the new funding formula for South African universities' Departments of Accounting}

The central government announced its research capacity-building objective in Notice 1196 of 1997 (South Africa 1997b), which set out the White Paper on Higher Education (Section 1.27(7)). The Minister of Education spelled out the intentions of the government in this regard in Section 5 of the National Plan for Higher Education published in February 2001 (Department of Education 2001). The plan provides, inter alia, for research at universities to be funded through a separate formula based on research outputs. The Ministry of Education published a policy document entitled, A new funding framework: how government grants are allocated to public higher education institutions, in February 2004. The formula for research output grants generated by research master's degrees and doctorates, as well as research publications at universities was stated in this policy document. This policy document was followed by another policy document entitled the Ministerial Statement on Higher Education Funding: 2006/7 to 2008/9, which announced the longer-term allocation policy for funds to universities, and specifically the allocations in respect of research outputs.

This fixed policy directly involves every Department of Accounting at every South African university in the central government's research capacity-building objective. It obliges every such department to devolve its research obligations to individual lecturers and to become part of the official research strategy at its university.

This is another development that will enforce radical changes in the academic culture of Departments of Accounting, despite their historical academic culture of focusing exclusively on the academic training of prospective chartered accountants.

\subsection{Departments of Accounting and IFAC's International Education Standards for Professional Accountants}

SAICA (s.a.(a)) holds a seat on the Council of the International Federation of Accountants (IFAC). IFAC expects its member bodies to comply, inter alia, with its Education Committee's International Education Standards for Professional Accountants (IFAC 2003:2). These standards "establish essential elements ... that education and development programs are expected to contain and that have the potential for international recognition, acceptance and application. Although these Standards cannot override authoritative local pronouncements, they are prescriptive in nature" (IFAC 2003:3). Consequently, SAICA is obliged to bring its syllabus content with regard to the academic training of prospective chartered accountants in line with IFAC's International Education Standards. The relevant standards require, inter alia, that the following "Professional Skills" requirement be met as part of the required intellectual skills: "...the capacity for inquiry, research, logical and analytical thinking, powers of reasoning, and critical analysis" (IFAC 2003:54).

One important result of this "Professional Skills" requirement by IFAC is that, whether or not it wishes to do so, SAICA will have to make room in the prescribed syllabi for exposing students, first, to research methodology and, second, to the conceptual 
foundations of accounting that will promote the students' "logical and analytical thinking, [and] powers of reasoning". Once SAICA sets these requirements, this will put pressure on the accredited universities to institute the subjects Research Methodology and Conceptual Foundations of Accounting in Departments of Accounting. The Higher Education Qualifications Framework also obliges Departments of Accounting to equip their honours students with research skills and "a high level of theoretical engagement and intellectual independence" (Department of Education 2007:25).

\subsection{The effect of the Higher Education Qualifications Framework on Departments of Accounting}

In October 2007, the policy document entitled The Higher Education Qualifications Framework was issued by the Ministry of Education in terms of Section 3 of the Higher Education Act 101 of 1997. This qualifications framework was designed, inter alia, to "enhance the development of a vibrant, high quality research system" (Department of Education 2007:10). The implementation date of the policy is 1 January 2009, but there will be a transition period to full compliance (Department of Education 2007:16). The proposed policy applies to existing and new programmes and qualifications (Department of Education 2007:16).

The stipulations relating to the "purpose and characteristics" of a bachelor's honours degree (Department of Education 2007:25) are of critical importance to Departments of Accounting. The compulsory research exposure and the need for the development of theoretical depth in students preparing for this qualification are clearly spelled out. With regard to the students' research exposure, the qualifications framework expects the following of the bachelor's honours degree: “[It] serves to consolidate and deepen the student's expertise in a particular discipline, and to develop research capacity in the methodology and techniques of the discipline" (Department of Education 2007:25).

Another important stipulation regarding the "purpose and characteristics" of the bachelor honours degree is that it "must include conducting and reporting research under supervision, worth at least 30 credits, in a manner that is appropriate to the discipline or field of study" (Department of Education 2007:25).

The Departments of Accounting at South African universities that offer a postgraduate diploma instead of a bachelor honours degree must note that the "purpose and characteristics" are, in broad terms, the same as those required for the bachelor honours degree, except that a "sustained research project is not required but the qualification may include conducting and reporting research under supervision" (Department of Education 2007:26).

Regarding the students' exposure to the conceptual foundations of accounting, it is clear that Departments of Accounting should also take cognisance of the following stipulation in the draft qualifications framework with regard to the bachelor's honours degree and the postgraduate diploma: "[It] demands a high level of theoretical engagement and intellectual independence" (Department of Education 2007:25-26).

In conclusion, it can be stated with some justification that in the immediate future, Departments of Accounting at South African universities whose academic programmes are accredited by SAICA will have to pay considerable attention, in cooperation with SAICA, to bringing their honours degree or postgraduate diploma programmes in accounting in line with the demands of the Higher Education Qualifications Framework. 
Five prominent developments requiring urgent action by Departments of Accounting were discussed above. The outcomes of the discussion of each of these developments have also answered the research question formulated above. It is indeed true that these developments are likely to irrevocably change the traditional academic culture of Departments of Accounting. One major advantage of the new culture will be that it will create a culture conducive to scholarly activity as an endeavour in Departments of Accounting that will be true to the essence of a university.

\section{Conclusions and recommendations}

Departments of Accounting at South African universities, particularly those whose academic programmes are accredited by SAICA, have reached a crossroads in fully meeting their academic mission. The impact of the developments in the academic environment discussed above will be, in the near future, to force these departments (in addition to taking on the responsibility for the academic training of prospective chartered accountants) to become prominent role players in scholarly activity, true to the essence of a university.

Finally, the following recommendations are made to expedite the development of a research culture in Departments of Accounting at South African universities:

(1) A good relationship should be maintained with SAICA. However, SAICA needs to be fully informed about the academic dilemma that Departments of Accounting face, namely the need to reconcile SAICA's requirements with their own urgent obligation to address the university's backlog in terms of its participation in scholarly activity. A healthy balance is required between the academic training of prospective chartered accountants and scholarly activity in Departments of Accounting. Garland's view, cited by Koornhof (2004:11), is highly apposite in this regard: "[F]inding the right balance between general and specialist [professional] education remains an important challenge to the modern university and faculty."

(2) SAICA must be persuaded to adapt its syllabi so that they will promote scholarly activity - indeed, that would be in line with IFAC's recommendations. Such an approach would not only better equip aspirant lecturers for their task, but also ensure that aspirant chartered accountants would be better equipped academically.

(3) With the help of SAICA, the large accountancy firms could be convinced of the importance of increasing the research responsibilities of Departments of Accounting in the university context; and they could be persuaded to make funds available for deserving research projects.

(4) SAICA could create space in Accountancy SA specifically to encourage new researchers (particularly university lecturers) to publish. A panel could be nominated to assess the research publications over a specified period and to reward deserving authors.

(5) SAICA could also nominate a panel to assess and reward the best research publications in both the South African Journal of Accounting Research and Meditari, say, over a period of one year.

(6) As a matter of urgency, the Southern African Accounting Association (SAAA) could identify experts (local and international) to promote research skills among its members in a practical way on a regional and national basis. 
(7) SAAA could use opportunities at its national and regional meetings to encourage the panel of judges, say, to afford small groups an opportunity to assess the best paper critically, for instance, on the basis of the paper's research process and to give feedback in a joint session.

(8) For at least the next 10 years, SAAA should add a standing item to its agendas for its regional and national agendas meetings entitled (for example) "Promoting research skills". Under such an item, matters such as the following could be discussed: research progress, current needs, new developments, internet use, research ethics, plagiarism, etc.

(9) As a matter of greater urgency, Departments of Accounting at South African universities need to ensure that their research outputs, particularly at master's and doctoral level, meet the requirements of scholarly activity, which should, of course, where necessary, be supported by the conceptual foundations of accounting (accounting theory) as part of the "body of accounting knowledge". The same responsibility applies to the editors and referees of the two well-known accounting research journals, namely the South African Journal of Accounting Research (http://www.sajar.co.za) and Meditari (http://www.meditari.org.za), which should ensure that research that is published in the two journals meets the requirements of contributing to scholarly activity.

(10) Heads of Departments of Accounting at South African universities could promote research in their departments by giving only those lecturers in the department who are actively engaged in research permission to do outside work (and also by making research a condition of appointment when appointing lecturers).

In this article, it is therefore argued that swift implementation of all the above recommendations will lead to visible progress in the establishment of a research culture in Departments of Accounting at South African universities in the next five years.

\section{Bibliography}

Cooper, D.R. \& Schindler, P.S. 2003. Business research methods. $8^{\text {th }}$ edition. New York: McGraw-Hill/Irwin.

CHE, vide Council on Higher Education.

Council on Higher Education.. 2003. Directory of South African education and training quality assurers and professional bodies. Pretoria: Council on Higher Education.

Council on Higher Education. 2004a. Founding document. Pretoria: Council on Higher Education.

Council on Higher Education. 2004b. Framework for institutional audits, policy document: Higher Education Quality Committee. Pretoria: Council on Higher Education.

Council on Higher Education. 2005. A good practice guide for quality management of research for higher education institutions. Pretoria: Council on Higher Education.

Cryer, P. 2006. The research student's guide to success. Berkshire: Open University Press.

Department of Education. 2001. National plan for higher education. Pretoria: Government Printer. 
Department of Education. 2004. A new funding framework: how government grants are allocated to public higher education institutions. Pretoria: Government Printer.

Department of Education. 2006. Ministerial statement on Higher Education funding: 2006/7 to 2008/9. Pretoria. Government Printer.

Department of Education. 2007. The Higher Education Qualifications Framework. Pretoria: Government Printer.

Duderstadt, J.J. 2000. A university for the $21^{\text {st }}$ century. Ann Arbor, Mich: University of Michigan Press.

Gray, R. \& McKernan, J. 2000. Accounting education: Crisis? What crisis? Accountancy and Finance Update, 5(2):10.

Harvard Business School. s.a. http://www.hbs.edu/aboutindex.html. [Accessed August 2007.]

Henning, E. 2004. Finding your way in qualitative research. Pretoria: Van Schaik.

Higher Education Quality Committee (HEQC). s.a. http://www.che.ac.za/heqc/heqc.php. [Accessed August 2007.]

IFAC, vide International Federation of Accountants.

International Federation of Accountants. 2003. International Education Standards for Professional Accountants. New York: IFAC.

Koornhof, C. 2004. Balancing general and professional education in the economic, financial and management sciences. University of Pretoria: Inaugural address.

Meditari. s.a. :http://www.meditari.org.za. [Accessed October 2007.]

Mouton, J. 2001. How to succeed in your master's and doctoral studies. Pretoria: Van Schaik.

Noble, K.A. 1995. The international education quotations encyclopaedia. Buckingham: Open University Press.

Oxford University. s.a. http://www.ox.ac.uk/aboutoxford/. [Accessed August 2007.]

Rossouw,G.J. 2006. Philosophy and the university: trends and temptations. University of Pretoria: Inaugural address.

SAICA, s.a.(a). https://www.saica.co.za/DisplayContent.asp?ContentpageID401. [Accessed July 2007.]

SAICA, s.a.(b). https://www.saica.co.za/documents/List_of accredited_ programmes_education06.pdf. [Accessed July 2007.]

SAICA. 2005. The Education Requirements of the South African Institute of Chartered Accountants for entry into Part 1 of the Qualifying Examination. Johannesburg: SAICA.

South Africa. 1995. South African Qualifications Authority (SAQA) Act 58 of 1995. Pretoria: Government Printer.

South Africa. 1997a. Higher Education Act 101 of 1997. Pretoria: Government Printer.

South Africa. 1997b. The White Paper on Higher Education (Notice 1196 of 1997). A programme for the transformation of Higher Education. Pretoria: Government Printer. 
Five recent developments' impact on traditional academic culture of Departments of Accounting at SA universities

South African Journal of Accounting Research. http://www.sajar.co.za. [Accessed October 2007.]

Stellenbosch University. s.a. http://www.sun.ac.za/rector/. [Accessed August 2007.]

Strydom, A.H. \& Strydom, J.F. 2004. Establishing quality assurance in the South Africa context. Quality in Higher Education, 10(2):101-113.

Sunday Times. 2007. Crucial time for SA universities as higher education goes global, s.a. http://www.thetimes.co.za/PrintEdition/Insight/Article.aspx?id=586480. [Accessed 26 October 2007.]

University of Cambridge. s.a. http://www.admin.cam.ac.uk/univ/mission.html. [Accessed August 2007.]

University of Cape Town. s.a. http://www.uct.ac.za/uct/about.php. [Accessed August 2007.]

University of Pretoria. s.a. http://www.up.ac.za/up/web/and/up/management/. [Accessed August 2007.]

University of the Witwatersrand. s.a. http;//www.wits.ac.za/depts/wcs/about.shmtl. [Accessed August 2007.]

West, A. 2006. A commentary on the global position of South African accounting research. Meditari Accountancy Research, 14(1):121-137. 